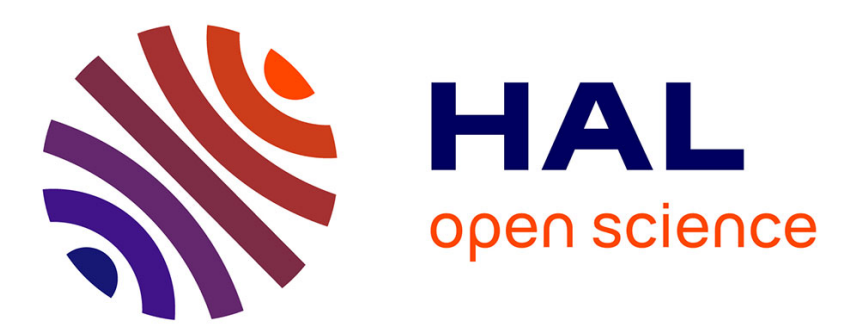

\title{
Thermohaline Contribution of the Caspian Sea Water Dynamic
}

\author{
Ayoub Moradi, Olivier de Viron, Laurent Métivier, Saeid Homayouni
}

\section{To cite this version:}

Ayoub Moradi, Olivier de Viron, Laurent Métivier, Saeid Homayouni. Thermohaline Contribution of the Caspian Sea Water Dynamic. Journal of Geography, Environment and Earth Science International, 2018, 17 (3), pp.1-10. 10.9734/JGEESI/2018/44294 . hal-01944919

\section{HAL Id: hal-01944919 https://hal.science/hal-01944919}

Submitted on 5 Dec 2018

HAL is a multi-disciplinary open access archive for the deposit and dissemination of scientific research documents, whether they are published or not. The documents may come from teaching and research institutions in France or abroad, or from public or private research centers.
L'archive ouverte pluridisciplinaire HAL, est destinée au dépôt et à la diffusion de documents scientifiques de niveau recherche, publiés ou non, émanant des établissements d'enseignement et de recherche français ou étrangers, des laboratoires publics ou privés. 


\title{
Journal of Geography, Environment and Earth Science International
}

\section{Thermohaline Contribution of the Caspian Sea Water Dynamic}

\author{
Ayoub Moradi ${ }^{1^{*}}$, Olivier de Viron ${ }^{2}$, Laurent Metivier ${ }^{3}$ and Saeid Homayouni ${ }^{4}$ \\ ${ }^{1}$ Iranian Space Research Center, Department of Remote Sensing, Bld. Teimouri, Tarasht, Tehran, \\ ${ }^{2}$ UMR LIttoral ENvironnement et Sociétés (LIENSs), University of La Rochelle, 2 Olympe de Gouges, \\ ILE, 17000 La Rochelle, France. \\ ${ }^{3}$ Institut National de l'information Géographique et Forestière (IGN), 35 Hélène Brion, Lamarck-B, \\ 75013 Paris, France. \\ ${ }^{4}$ Department of Geography, Environment and Geomatics, University of Ottawa, Ottawa, Canada.
}

Authors' contributions

This work was carried out in collaboration between all authors. Author AM carried out the steric calculations, including methodology consideration, data selection, data processing, and comparisons. He performed the result analysis and drafted the manuscript. Author OV participated in GRACE data processing and in analysing the impact of the steric circulation on the Lake dynamics. He also participated in the design, coordination of the study and helped to draft the manuscript. Author LM participated in altimetry data processing and accuracy assessment. He also helped in literature searches. Author SH helped in the analysis of results and improving manuscript structure. All authors read and approved the final manuscript.

Article Information

DOI: $10.9734 / J G E E S I / 2018 / 44294$ Editor(s):

(1) Dr. Pere Serra Ruiz, Department of Geography, Universitat Autònoma de Barcelona, Spain. Reviewers:

(1) Williams Kweku Darkwah, Hohai University, China. (2) Beata Messyasz, Adam Mickiewicz University in Poznan, Poland. (3) Kabi Pokhrel, Tribhuvan University, Nepal. Complete Peer review History: http://www.sciencedomain.org/review-history/26623

Original Research Article

Received 16 July 2018

Accepted 25 September 2018

Published 11 October 2018

\section{ABSTRACT}

This article investigated the principal reason for water circulations in the Caspian Sea. Unlike other inland water bodies, and similar to the open seas, the Caspian Sea shows regular water circulations which are not explained by the wind. The Steric contribution of water level fluctuations was studied in this article by two approaches: one from remote sensing and climatology data, and 
the other, from space altimetry and gravimetry data. The approaches are fundamentally different: the first approach directly observes and measures the steric fluctuations, while, the second approach estimates the steric fluctuations by analysing their causing factors such as water temperature and salinity. Analysis of over 13 years data showed that estimations from these two approaches are consistent. Based on the results, the Steric Sea Level (SSL) included a seasonal cycle of about $8.5 \mathrm{~cm}$ and a seasonal topography of 4 and $7 \mathrm{~cm}$ in winter and summer respectively. The seasonal water circulations observed in the lake was consistent with the geostrophic response to estimated steric topography. Moreover, the results demonstrated that the seasonal water surface topography is the reason for water circulation in the Caspian Sea.

Keywords: Steric Sea level; Sea surface temperature (SST); Sea surface topography; Caspian Sea.

\section{INTRODUCTION}

Located in northwest Asia and with a surface area of $371,000 \mathrm{~km}^{2}$, the Caspian Sea is the world's most substantial inland water body, with 40 to $44 \%$ of the total lacustrine waters of the world. The annual inflow to the Caspian Sea comes from more than 130 rivers. The Volga River contributes the most, whereas the only natural outgoing flux is evaporation from the lake surface. Sea level fluctuations of the order of a few meters have been recorded over the last centuries; which are mostly addressed to natural climate variabilities [1-4]. The lake also shows seasonal fluctuations caused by the change in the lake water balance inducing variations in the total water content [5]. Beside seasonal changes of input water, a steric effect also can cause seasonal fluctuations. The steric level changes due to the variations of water density. As well, the effect of wind blowing over the lake could deform its surface locally.

Whereas the global Caspian Sea level has been the topic of several studies $[6,7,8]$, the water surface topography of the lake has not been investigated to date. The lake itself is only sparsely monitored through in-situ technique, which makes its evolution and dynamics challenging to study. On the other hand, to investigate such a vast lake, remote sensing observations are essential. In particular, since 1992, a series of satellite altimetry missions, beginning with the TOPEX/Poseidon satellite have directly measured sea surface heights. Satellite altimetry measurements allow continuous and homogeneous monitoring of the water surface topography.

With the GRACE (Gravity Recovery And Climate Experience) mission, starting in 2002, it is now possible to quantify the spatio-temporal change of total water storage and its associated water level. This allows determining the part of sea level resulting from the change of the total mass content. Space altimetry, on the other hand, measures the apparent water level change [9], which indicates integrated mass and volume effects. Therefore, with combining GRACE and altimetry estimations, the part of the sea level change associated with water density variations can be separated from the region related to changes in the total water content, as previously studied $[8,10]$. Water temperature measurements are used globally to estimate water density variations and general circulations within the oceans [11]. Beside water temperature, water salinity data was used in a limited number of studies [12]. Together temperature and salinity can control the water volume variations. However, the effect of temperature is stronger than salinity [13] due to the stronger seasonal variation of temperature. The salinity effect includes only about $10 \%$ of the total steric effect in the oceans [14]. This portion should be smaller in the case of the Caspian Sea because its salt content is about one-third of the oceans.

The steric effect could have a role in seasonal and inter-annual scales. A portion of the global sea level rise during the last decades refers to water expansion as the results of water temperature increments. Water thermal expansion includes about one-third of total sea level rise [15]. This rate reaches up to about 0.7 to $1 \mathrm{~mm}$ per year [16]. However, seasonal variations of steric effect cause global water circulations that have an essential role in global climate and marine biosphere. Oceanic water circulations have been associated with steric effects. Inland water bodies usually do not experience water circulations. Due to its largeness, however, several works [17-21] reported a cyclonic surface water circulation in deep central and southern regions.

Nonetheless, the physical explanation for those currents remains to be found. The dynamics of 
the Caspian Sea is not very well known, nor well understood. This article aims to investigate the presence of a steric effect in the Caspian Sea and see how does the steric impact controls the lake water circulation, considering its amplitude and spatio-temporal variations.

\section{DATA}

To investigate water density, water temperature, and salinity data are required. Considering that the total input of salt via the rivers is negligible, 3D models for temperature and salinity are reconstructed utilising remotely sensed Sea Surface Temperature (SST), and temperature/salinity climatology profiles. The NOAA National Ocean Data Center distributes the SST data. These data are reproduced through an optimum interpolation of Advanced Very High Resolution Radiometer (AVHRR), [22]. Temperature and salinity profiles were obtained from in-situ sounding by World Ocean Atlas 2009 -WOA- $[23,24]$. To compute the total water mass changes, three different solutions of GRACE GRGS were processed. The data used in both approaches are summarised in Table 1.

\section{METHODOLOGY}

Two different approaches constructed the time series of steric fluctuation; 1) computing the water density variations, and 2) subtracting the water level deduced from the GRACE data to the water level obtained from space altimetry.

\subsection{Steric Sea Level from SST and Climatology Data}

The sea water is well stratified in nature. The topmost layer is mixed, and a thin homogeneous layer and a thermocline layer is situated beneath the mixed layer. The later layer shows a strong vertical temperature gradient, below which only negligible water density variations occur. Based on the Atlas data of temperature and salinity $[23,24]$, the mixed layer is thinner than $10 \mathrm{~m}$ in the Caspian Sea. Indeed, the temperature and salinity gradients over the first ten meters are more significant than the typical value for a mixed layer. Boehrer and Schultze, [25] estimated the thermocline depth for several lakes in various geographic areas and showed a robust correlation between the mean lake depth and the depth of its thermocline. The mean thermocline depth of the Caspian Sea is not specified yet. However, Peeters et al. [26] estimated a thermocline depth of about $90 \mathrm{~m}$ and $160 \mathrm{~m}$, in the deep central basin and the southern basin of the lake respectively. Jamshidi [27] observed a $40 \mathrm{~m}$ deep thermocline in the south of Caspian Sea, in an area closed to the coast with $100 \mathrm{~m}$ average depth.

Therefore, the study expects that the mean thermocline boundary of the Caspian Sea stands between 110 and $150 \mathrm{~m}$. This limit is consistent with the estimations from Boehrer \& Schultze, [28] for some other lakes around the world. To model mean water density variations above the thermocline depth, the Atlas data are only appropriate available data for the region of study. Climatology profiles from the Atlas are classically provided at 24 standard levels in the oceans (down to $1500 \mathrm{~m}$ ). However, for the Caspian Sea, only levels $0,10,20$ and $30 \mathrm{~m}$ are available. Then the World Ocean Atlas data linearly extrapolated down to the thermocline depth; as only the order of magnitude is required, this crude method was adapted for the present study. By combining SST with WOA models, the temporally and spatially varying bulk temperatures were computed.

With about $210 \mathrm{~m}$ of average depth over the Caspian Sea, one can neglect the compressibility of water column [29]. The water density time variations between the surface and thermocline depth were calculated from temperature and salinity using equations from McCutcheon et al. [30], and integrated vertically to obtain the steric water level fluctuations (Equation 1). The estimated steric fluctuations for thermocline lower boundary at $110 \mathrm{~m}$ and $150 \mathrm{~m}$ are shown in Fig. 1.

$\rho_{w}=f\left(T_{w}, S_{w}\right), S S L_{S S T / S S S}=\int_{0}^{T} \Delta \rho_{w}$

\subsection{SSL from Space Altimetry and Gravimetry Data}

The stabilised GRACE models from the solutions processed by GRGS and JPL were used in this approach. The main steps of this solution are the followings:

1. Subtraction of the mean gravity fields.

2. Calculation of the density and Equivalent Water Height on a grid of 0.5-by-0.5 degree.

3. Masking the lake extent to isolate the signal of the lake.

4. Averaging grids over the lake surface, to estimate the equivalent water height anomalies. 
5. Estimating the leakage in/out effects and correcting the estimations of equivalent water height.

After removing the inter-annual variations from the water level time series, the steric sea level change is estimated as follow:

$S S L_{\text {alti/gravi }}=\left(S L A_{\text {altimetry }}-S L A_{\mathrm{GRACE}}\right)-$
$\left(S L A_{\text {nonsteric }}\right)$

The time series show a robust seasonal cycle affected by strong irregular fluctuations. This study focused on the seasonal cycle, which is isolated by computing a composite annual period. The curve of $8.3 \mathrm{~cm}$ amplitude results in the minimum residual of remaining random fluctuations (Fig. 2).

\subsection{Accuracy Assessment}

In the literature, an uncertainty of about 1 to 1.7 ${ }^{\circ} \mathrm{K}$ is observed for the NOAA derived SST over the open seas $[31,32,33,34,35]$. However, an uncertainty level of $1.83^{\circ} \mathrm{C}$ in SST data was

found for the Caspian Sea. The standard errors for the climatologic means of WOA were produced by the distributor [36], which showed that the maximum standard errors in all depths in the Caspian Sea were $1.5^{\circ} \mathrm{C}$ and $0.3 \mathrm{~kg} / \mathrm{m}^{3}$ for temperature and salinity respectively. The results showed that the sea steric variation was 1.95 $\mathrm{mm}$ per $0.1 \mathrm{~g} / \mathrm{kg}$ for the salinity change; and 2.95 $\mathrm{mm}$ and $3.75 \mathrm{~mm}$ per ${ }^{\circ} \mathrm{C}$ for the temperature change in winter and summer respectively. Thus:

$E_{\mathrm{T} \_ \text {summer }}=2 * 3.75=7.5 \mathrm{~mm} \quad, \quad E_{\mathrm{T} \_ \text {winter }}=2 *$ $2.95=5.9 \mathrm{~mm}, E_{\text {Salinity }}=2 * 1.95=3.9 \mathrm{~mm}$

Therefore, the overall error of the steric sea level derived from the SST/SSL was estimated as follow:

$$
E_{\text {sthe teric } \text { SST }_{\text {T }}}=\sqrt{(7.5)^{2}+(3.9)^{2}}=8.4 \mathrm{~mm}
$$

Error of steric sea level in summer

$E_{\text {steric }_{\mathrm{SST}}}=\sqrt{(5.9)^{2}+(3.9)^{2}}=7.1 \mathrm{~mm}$

Error of steric sea level in winter (5)

Table 1. List of the datasets used

\begin{tabular}{|c|c|c|c|c|c|}
\hline Parameter & Dimension & Dataset & Period & $\begin{array}{l}\text { Temporal } \\
\text { resolution }\end{array}$ & $\begin{array}{l}\text { Spatial } \\
\text { resolution }\end{array}$ \\
\hline \multirow[t]{2}{*}{ Temperature } & Horizontal & NOAA SST & $2000-2012$ & Daily & $0.25^{\circ}-0.25^{\circ}$ \\
\hline & Vertical & WOA 2009 & Static & Monthly Mean & $1^{\circ}-1^{\circ}$ \\
\hline \multirow[t]{2}{*}{ Salinity } & Horizontal & WOA 2009 & Static & Monthly Mean & $1^{\circ}-1^{\circ}$ \\
\hline & Vertical & WOA 2009 & Static & Monthly Mean & $1^{\circ}-1^{\circ}$ \\
\hline \multirow{3}{*}{$\begin{array}{l}\text { Water Mass } \\
\text { Anomaly }\end{array}$} & Horizontal & GRACE GRGS RL-2 & $2002-2012$ & 10 day & $400 \mathrm{~km}$ \\
\hline & & GRGS RL-3 & $2003-2012$ & Monthly & $250 \mathrm{~km}$ \\
\hline & & JPL RL-5 & $2003-2015$ & Monthly & $200 \mathrm{~km}$ \\
\hline
\end{tabular}

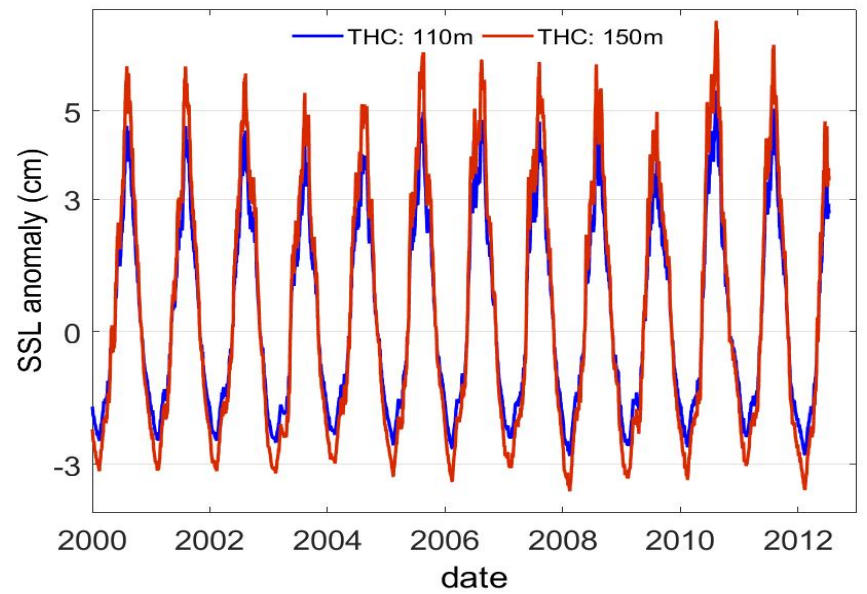

Fig. 1. Seasonal Steric fluctuations of the Caspian Sea level, calculated for the estimated minimum $(T H C=110)$ and maximum $(T H C=150)$ thermocline depths 


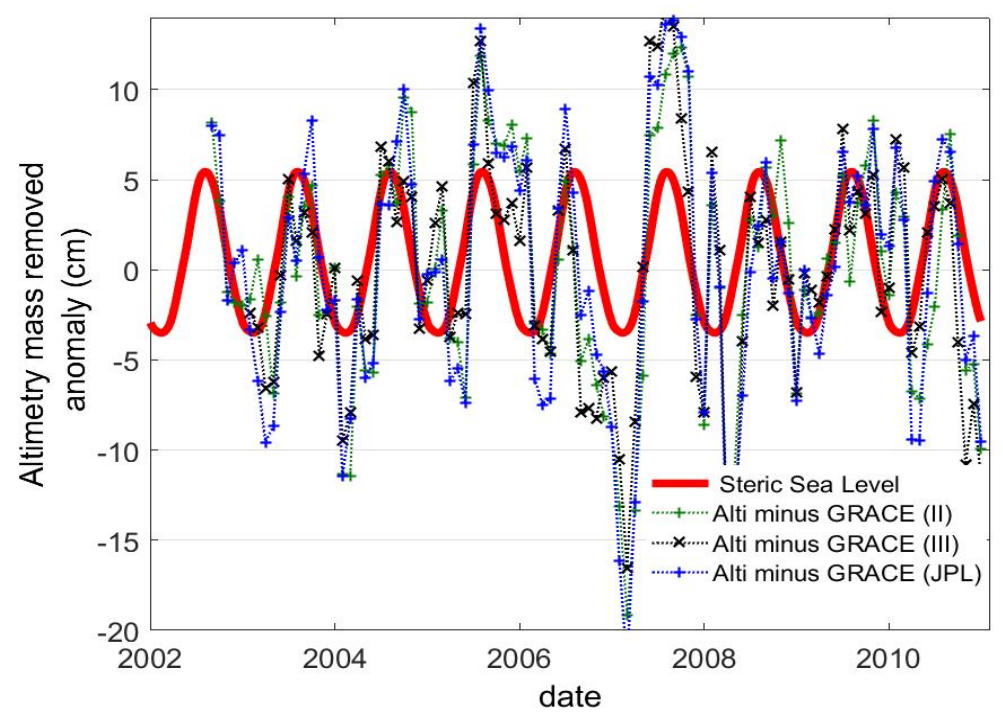

Fig. 2. Altimetry minus GRACE: all signal (dotted lines), fitted seasonal signal (red line)

Having a correlation coefficient of 0.66 , water temperature and salinity showed a dependency. Thus, the true error is half the covariance between two kinds of error. Note that, to this point, there was not enough information to make an accurate assessment for the thermocline depth. For this reason, two shallow and deep limits for the lake thermocline were introduced.

The formal mapping errors were provided by AVISO Live Access Server (LAS) for Sea Level Anomalies. Based on these maps, the error in the Caspian Sea was $3.22 \mathrm{~cm}$ on average. Previous studies reported a precision range from 2 to $3.5 \mathrm{~cm}$ in water thickness estimated from
GRACE data [7,37-40]. The errors in GRACE estimations decreased at higher latitudes [7], including the Caspian Sea region. By considering the dispersion of measurements, the investigation of uncertainty showed that the uncertainties were 3.16 and $2.84 \mathrm{~cm}$ for GRACE RL02 and RL03 time series respectively. Overall uncertainty of steric sea level derived from altimetry/GRACE is as follow:

$$
\begin{aligned}
& E_{\text {steric }} \text { Alti/GRACE } \\
& E_{\text {steric }}=\sqrt{\left(E_{\text {Alti }} / \mathrm{G} 02\right.}=\sqrt{(3.22)^{2}+\left(E_{G R A C E}\right)^{2}} \text {, then } \\
& E_{\text {steric }} \text { Alti } / \mathrm{G} 03 \\
& =\sqrt{(3.22)^{2}+(2.84)^{2}}=4.5 \mathrm{~cm}
\end{aligned}
$$

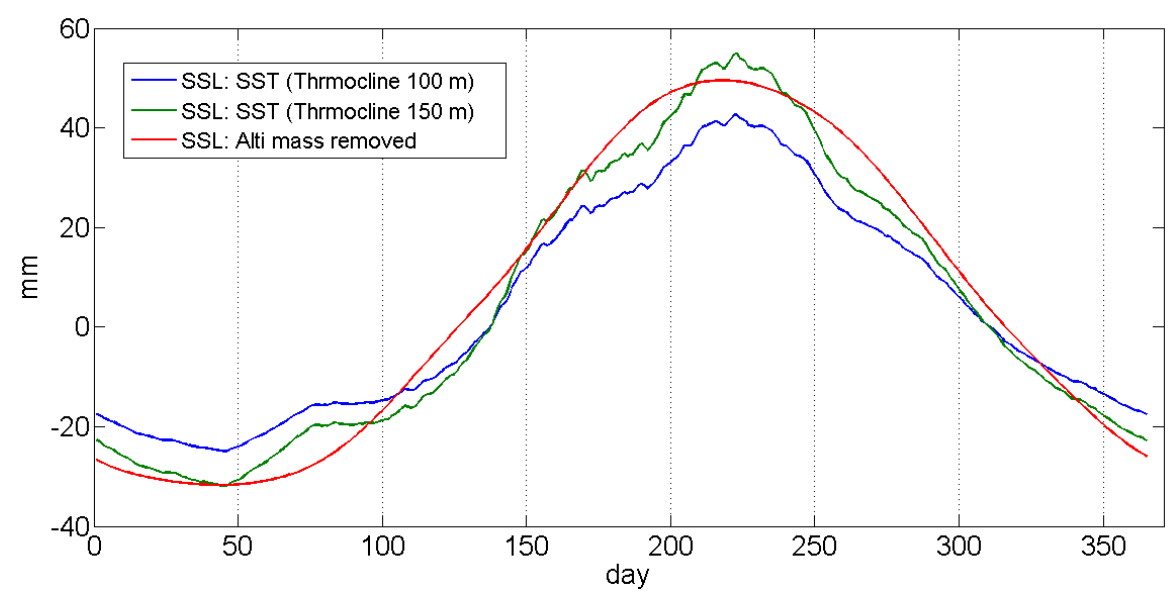

Fig. 3. Mean seasonal SSL derive from 1) SST data (calculated for two thermocline depths of $110 \mathrm{~m}$ and $150 \mathrm{~m}$ ), and 2) altimetry/GRACE 
The mean seasonal cycle of SSL was estimated by fitting over nine years of data. The final uncertainty was thus $\sqrt{9}$ times smaller, due to averaging, then:

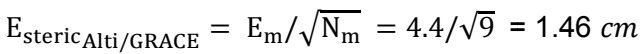

Where, $E_{\mathrm{m}}$ is the measurement error, and $N_{\mathrm{m}}$ is the number of measurements. Without considering the thermocline precision, the SSTbased SSL has higher accuracy than the Altimetry and GRACE-based one.

\subsection{Comparison of the Two Mean SSL Estimations}

SST steric estimation is expected to be more precise and better sampled than the altimetry and GRACE one, but strongly depends on the unknown thermocline bottom depth. Consequently, it was decided to use the SSTbased estimated and fix the thermocline lower boundary utilising the altimetry and GRACE estimate results. To reconcile the amplitude of the seasonal cycle from the two methods, the study found an average depth of thermocline limit at $145 \mathrm{~m}$. By applying this thermocline limit, the magnitude of seasonal SSL was about $8.5 \mathrm{~cm}$ (Fig. 3).

\section{IMPACTS ON THE LAKE CIRCULATION}

\subsection{Lake Topography Variations}

Based on the altimetry measurements, which has also been confirmed by the monitoring of the shorelines using MODIS images [5], the lake topography exhibits a seasonal signal, as illustrated in Fig. 4.

The sea surface topography determined from altimetry was corrected for the contribution from steric sea level variations (Fig. 5 A). The remaining topography features, appearing mostly in the northern part of the lake, resulted from river discharges and winds. These topographies occur at the high frequencies (Fig. 5 B). The high frequencies topography of the sea surface filtered; the resulted map (Fig. $5 \mathrm{C}$ ) shows that no deep-shallow topography remains; implicating that, the steric associated topography was appropriately removed.

\subsection{Impact of the Steric Circulation on the Lake Dynamics}

The non-steric contribution to the sea level did not present seasonal lake-scale topography. Thus the seasonal water circulation in the lake was induced by the steric component [41]. Based on the steric elevation, the induced geostrophic current pattern was estimated using the classical geostrophic equations:

$$
\begin{aligned}
& u_{g}=-\frac{g}{f} \frac{\partial Z}{\partial y} \\
& v_{g}=\frac{g}{f} \frac{\partial Z}{\partial x}
\end{aligned}
$$

Where $\boldsymbol{u}_{\boldsymbol{g}}$ and $\boldsymbol{v}_{\boldsymbol{g}}$ are the geostrophic zonal (along $x$ ) and meridional (along $y$ ) velocities, $\boldsymbol{g}$ is the gravity acceleration, $f$ is the Coriolis factor, and $Z$ is the water elevation.

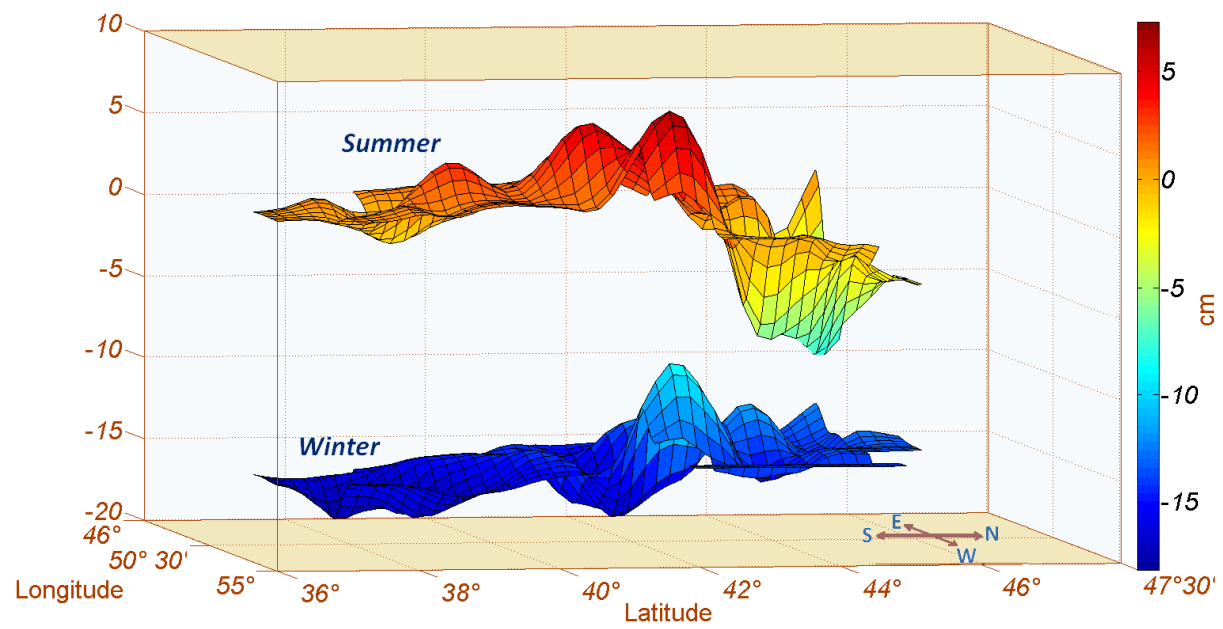

Fig. 4. Water level fluctuation in the lake, derived from the multi-mission dataset (averages over 19 years) 


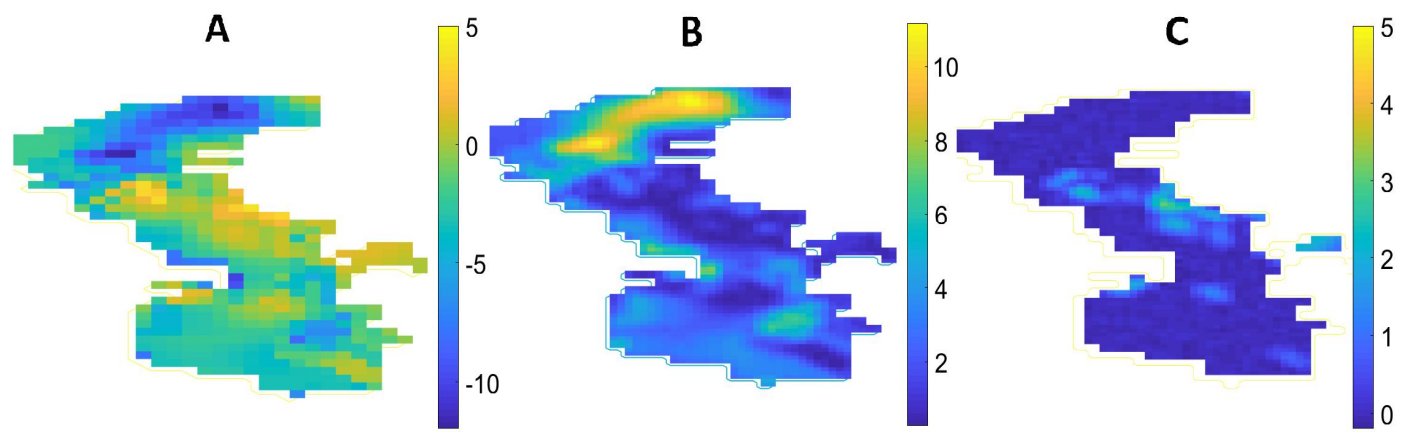

Fig. 5. Removing high-frequency topography using a Fast Fourier Transform: $A$ is water level fluctuations in summer (altimetry steric removed), B shows high-frequency topographies, and $\mathrm{C}$ is water level fluctuations after eliminating high-frequency topographies

Because of the Earth rotation, in the northern hemisphere, the currents tend to turn right, and a cyclonic water circulation always forms around a valley on sea surface due to the Coriolis effect [41]. The computed circulation pattern agrees with the observed cyclonic currents in winters (Fig. 6); when the central and southern parts of the sea stand get lower than other regions, causing a valley like form. These two parts are split by the sea bottom topography, which forms the two separate cyclones in the water circulation. Ibrayev et al. [21] have limited the cyclonic gyres to December-January; and they have modelled south, south-westward surface current during February-July. This model, especially in the southern part, is similar to an anti-cyclonic circulation, as expected from the results. In the North-West, the current patterns are not consistent with what would be expected from the steric topography, but the flow of the Volga rivers, which enter the sea in that area, contributes to the current dynamics in that part of the Lake. In addition, Ibrayev et al. [21] have assimilated the minimum sea surface topography in July $(7.5 \mathrm{~cm})$ and the maximum in December $(15 \mathrm{~cm})$. Their estimation for July is consistent with the present result, but the December's estimated topography is four times larger than the estimation in winter. It is neither consistent with the altimetry records.
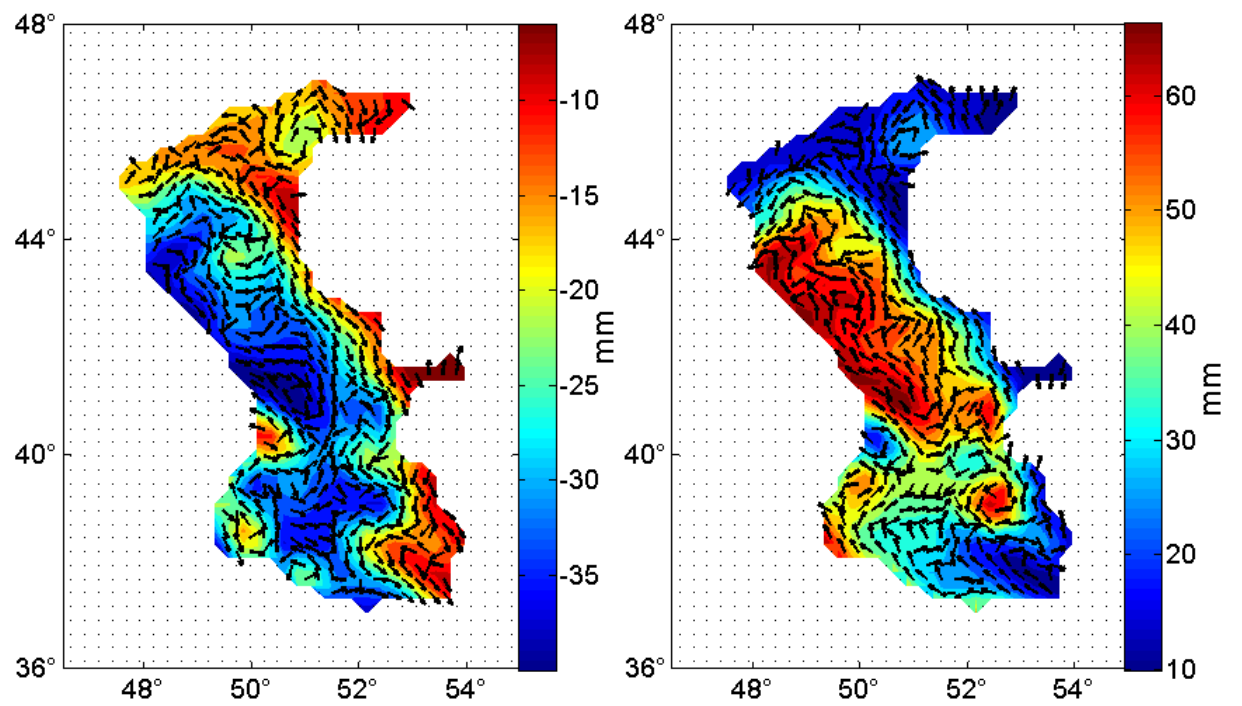

Fig. 6. Map of the direction of the geostrophic currents associated with the SSL in summer (right) and winter (left). Note that the size of the arrow is normalised and should not be interpreted 


\section{CONCLUSIONS}

Among inland water bodies, the Caspian Sea has a particular specification, as it shows regular water circulations. Studying the fluctuation level of the Caspian Sea is challenging due to the lack of in-situ data. Moreover, a large annual river discharge into the lake makes it challenging to measure steric fluctuations and separate it from the total annual cycle. In this paper, considering these conditions, the lake steric fluctuations and surface topography were investigated using two differently applicable approaches. The first approach was observing steric effect by integration of satellite gravimetry and altimetry. However, the second approach utilised physical water parameters (temperature and salinity) to estimate the steric fluctuations. The strong point of the applied approaches was that they studied one phenomenon in both perspectives, one approach discussed that how the steric effect in the lake was expected to be, and the other one, reported the actual situation of steric effect in the lake.

Due to the low spatial resolution of GRACE observations, the first approach did not allow to see the local steric topography, whereas this topography was clearly discovered in the second approach. The steric topography is 4 and $7 \mathrm{~cm}$ in winter and summer respectively. This topography is essential to explain the seasonal water circulations which were not previously justified. The computed geostrophic currents associated with the steric topography allowed us to explain the observed circulations of the Caspian Sea.

A direct comparison of the two approaches on the average SSL signal showed a fair agreement, which gives us the confidence to interpret the steric induced topography. It is worth mentioning that the low resolution of some data probably causes most of the irregularity in the computed water topography. Notably, a higher resolution bathymetry map would improve the features because the bathymetric separation between central and southern regions of the lake are not correctly reflected in the $0.5^{\circ}$ by $0.5^{\circ}$ depth map. Temperature plays a dominant role in steric effect effects. It explains more than $90 \%$ of steric fluctuations. Therefore temperature profiles to a greater depth would allow for a better thermocline determination, and consequently, allow for a more precise steric topography computation. Inter-comparison of two approaches permitted balancing a thermocline depth of about $145 \mathrm{~m}$ in the Caspian Sea, which are consistently comparable to the other lakes. Nevertheless, the agreement of the estimated current field resulting from the steric topography with what has been observed in the Caspian Sea dynamics confirms that the present approach has adequately retrieved the major features of the signal.

\section{ACKNOWLEDGEMENTS}

This study was supported by a grant from the French Government (BGF). The World Ocean Atlas data are made available by NOAA NODC. The GLDAS data used in this study were acquired as part of the mission of NASA's Earth Science Division and archived and distributed by the Goddard Earth Sciences (GES) Data and Information Services Center (DISC). Altimetry data are available online on Hydroweb. The contribution of $\mathrm{O}$. de Viron was financially supported by the Institut Universitaire de France, and by the CNES through the TOSCA program, as an exploitation of the GRACE and altimetry missions. We would also like to thank Jean-Marie Beckers from the University of Liège, Belgium, for a useful discussion of our results.

\section{COMPETING INTERESTS}

Authors have declared that no competing interests exist.

\section{REFERENCES}

1. Rodionov SN. Global and regional climate interpretation: The Caspian Sea experience. Kluwer Academic Publishers, Boston; 1994.

2. Cazenave A, Bonnefond P, Dominh $\mathrm{K}$, Schaeffer P. Caspian sea level from TOPEX/POSEIDON altimetry: Level now falling. Geophys. Res. Lett. 1997;24:881884.

3. Arpe K, Bengtsson L, Golitsyn GS, Mokhov II, Semenov VA, Sporyshev PV. Connection between Caspian sea level variability and ENSO. Geophys. Res. Lett. 2007;27(17):2693-2696.

DOI: 10.1029/1999GL002374

4. Shiklomanov A, Georgievski V, Kopaliani ZD. Water balance of the Caspian Sea and reasons of water level rise in the Caspian Sea. Paris, UNESCO, Intergovernmental Oceanographic Commission, Workshop Report 28, Supplement, 1-27; 1995.

5. Moradi A, Metivier L, de-Viron O, Calmant $S$, Mering C. Evaluation of MODIS data for 
improved monitoring of the Caspian Sea. International Journal of Remote Sensing; 2014.

DOI: 10.1080/01431161.2014.943324

6. Nerem S, Leuliette E, Cazenave A. Present-day sea level change. Geoscience C. R. 2006;338(1415):1077-1083.

7. Swenson S, Wahr J. Multi-sensor analysis of water storage variations of the Caspian Sea. Geophys. Res. Lett. 2007;34:L16401. DOI: 10.1029/2007GL030733

8. Landerer FW, Jungclaus JH, Marotzke J. Regional dynamic and steric sea level change in response to the IPCC-A1B scenario. J. Phys. Oceanogr. 2007;37(2): 296-312.

DOI: $10.1175 / J P O 3013.1$

9. Rosmorduc V, Benveniste J, Bronner E, Dinardo S, Lauret O, Maheu C, et al. Radar Altimetry Tutorial, Editors: J. Benveniste, N. Picot. 2011.

Available:http://www.altimetry.info

10. Lombard A, Garcia D, Ramillien G, Cazenave A, Biancale R, Lemoine JM, et al. Estimation of steric sea level variations from combined GRACE and Jason-1 data. Earth and Planetary Science Letters. 2007;254(1-2):194-202.

DOI: 10.1016/j.epsl.2006.11.035

11. Lombard A, Cazenave A, Traon Le PY, Ishii M. Contribution of thermal expansion to present-day sea-level change revisited. Global and Planetary Change. 2005;47:116.

12. Tsimplis NM, Rixen M. Sea level in the Mediterranean Sea: The contribution of temperature and salinity changes. Geophysical Research Letters. 2002; 29(23):2136.

DOI: 10.1029/2002GL015870,.

13. Antonov JI, Levitus S, Boyer TP. Steric sea level variations during 1957-1994: Importance of salinity. J. Geophys. Res. 2002;107(C12):8013.

DOI: 10.1029/2001JC000964

14. Jackett $D R$, Mcdougall $T J$, England $M H$, Hirst AC. Thermal expansion in ocean and coupled general circulation models. Journal of Climate. 1999;13:1384-1404.

15. National Research Council, Division on Earth and Life Studies, Ocean Studies Board, Board on Earth Sciences and Resources, Committee on Sea Level Rise in California, Oregon, and Washington. Sea-Level Rise for the Coasts of California, Oregon, and Washington. National Academies Press; 2012. ISBNs:
Paperback: 978-0-309-25594-3, Ebook: 978-0-309-25597-4.

DOI: https://doi.org/10.17226/13389

16. Wigley TML, Raper SCB. Thermal expansion of sea water associated with global warming. Nature. 1987;330:127131.

17. United Nations Environment Programme Global Resource Information Database (UNEP/ GRID).

Available:http://www.gridw.pl/en/

18. Zenkevitch LA. Caspian and Aral Seas, in treatise on marine ecology and paleoecology. Editor JW Hedgpeth. Mem. Geol Soc., America. 1957;67(1):891-916.

19. Guelorget O, Perthuisot JP. The paralic realm geological, biological and economic expressions of confinement. Report Prepared for the Mediterranean Regional Aquaculture Project, Food And Agriculture Organization Of The United Nations (FAO), Rome; 1989.

20. Lednev VA. Techeniya Severnogoi Srednego Kaspiya, Morskoy Transport, Moscow, USSR; 1943. Russian

21. Ibrayev RA, Ozsoy E, Schrum C, Sur HI. Seasonal variability of the Caspian Sea three-dimensional circulation, sea level and air-sea interaction. Ocean Science. 2010;6:311-329.

22. Reynolds RW. What's New in Version 2. OI SST NOAA. Technical Report; 2009.

23. Locarnini RA, Mishonov AV, Antonov JI, Boyer TP, Garcia HE, Baranova OK, et al. World Ocean Atlas 2009, Volume 1: Temperature. S. Levitus, Ed. NOAA Atlas NESDIS 68, U.S. Government Printing Office, Washington, D.C. 2010;184.

24. Antonov JI, Seidov D, Boyer TP, Locarnini RA, Mishonov AV, Garcia HE, et al. World Ocean Atlas 2009, Volume 2: Salinity, S. Levitus, Ed. NOAA Atlas NESDIS 69, U.S. Government Printing Office, Washington, D.C.; 2010.

25. Boehrer B, Schultze M. Stratification of lakes. Reviews of Geophysics. 2008;46:127.

26. Peeters F, Kipfer R, Achermann D, Hofer $M$, Aeschbach-Hertig W, Beyerle U, et al. Analysis of deep-water exchange in the Caspian; Sea based on environmental tracers. Deep Sea Research. 1999;47(1): 621-654.

27. Jamshidi S, Abu-Bakar, Noordin Md. Temperature, salinity and density measurements in the coastal waters of the Rudsar, South Caspian Sea. Journal of the 
Persian Gulf (Marine Science). 2010;1(1): 27-35.

28. Stewart RH. Introduction to Physical Oceanography. Texas A \& M University; 2008.

29. McCutcheon SC, Martin JL, Barnwell TO. Water quality in Maidment, DR. Handbook of Hydrology, McGraw Hall inc. ISBN: 9780070397323; 1993.

30. Liang $X$, Ignatov A. Monitoring of IR Clearsky Radiances over Oceans for SST (MICROS): Near-real time web-based tool for monitoring CRTM - AVHRR Biases. MICROS Web-Based Tool. JGR Manuscript. 2010;1.

31. Li X, Pichel W, Clemente-Colon P, Krasnopolsky V, Sapper J. Validation of coastal sea and lake surface temperature measurements derived from NOAA/AVHRR data. Int. J. Remote Sens. 2001;22:1285-1303.

32. Oesch DC, Jaquet JM, Hauser A, Wunderle S. Lake surface water temperature retrieval using advanced very high resolution radiometer and Moderate Resolution Imaging Spectroradiometer data: Validation and feasibility study. J. Geophys. Res. 2005;110:C12014.

DOI: 10.1029/2004JC002857

33. Reynolds RW, Chelton DB, Roberts-Jones J, Martin MJ, Menemenlis D, Merchant CJ. Objective determination of feature resolution in two sea surface temperature analyses. J. Climate. 2013;26:2514-2533. DOI:http://dx.doi.org/10.1175/JCLI-D-1200787.1
34. Sasha PD, Liang $\mathrm{X}, \mathrm{Xu} F$. Towards community consensus SSTs and clear-sky radiances from AVHRR. Presentation by: SST Science Team Meeting. NOAA/NESDIS and CSU/CIRA; 2010.

35. WOA Frequently Asked Questions. Available:https://www.nodc.noaa.gov/OC5/ wod-woa-faqs.html

36. Available:http://data.nodc.noaa.gov/las/get $\underline{\text { Ul.do }}$

37. Wahr J, Swenson S, Velicogna I. Accuracy of GRACE mass estimates. Geophys. Res. Lett. 2006;33:L06401.

DOI: 10.1029/2005GL025305

38. Klees R, Liu X, Wittwer T, Gunter BC, Revtova EA, Tenzer R, et al. A comparison of global and regional GRACE models for land hydrology. Surv. Geophys. 2008; 29(45):335-359.

DOI: $10.1007 / \mathrm{s} 10712-008-9049-8$

39. Longuevergne L, Scanlon BR, Wilson CR. GRACE hydrological estimates for small basins: Evaluating processing approaches on the high plains aquifer, USA. Water Resources Res. 2010;46(11). DOI: $10.1029 / 2009 W R 008564$

40. Valty $\mathrm{P}$, de-Viron $\mathrm{O}$, Panet I, van-Camp $\mathrm{M}$, Legrand $\mathrm{J}$. Assessing the precision in loading estimates by geodetic techniques in Southern Europe. Geophysical Journal International. 2013;194(3):1441-1454. DOI: $10.1093 / g j i / g g t 173$

41. Marshall J, Plumb RA. Atmosphere, Ocean and climate dynamics, an introductory text. Academic Press. 1979;344. ISBN: $008095457 X, 9780080954578$

(c) 2018 Moradi et al.; This is an Open Access article distributed under the terms of the Creative Commons Attribution License (http://creativecommons.org/licenses/by/4.0), which permits unrestricted use, distribution, and reproduction in any medium, provided the original work is properly cited.

Peer-review history:

The peer review history for this paper can be accessed here: http://www.sciencedomain.org/review-history/26623 